\title{
Development of the Human Antibody Repertoire
}

\author{
ELISABETH E. ADDERSON, J. MARTIN JOHNSTON, PENELOPE G. SHACKELFORD, AND \\ WILLIAM L. CARROLL \\ Department of Pediatrics and Program in Human Molecular Biology and Genetics, University of Utah, Salt Lake \\ City, Utah 84112 [E.E.A., J.M.J., W.L.C.], and Department of Pediatrics, Washington University School of \\ Medicine, St. Louis, Missouri 63110 [P.G.S.]
}

Humans are confronted with a vast array of foreign antigens, necessitating the generation of a large number of protective Ig molecules. It is estimated that the immune system is capable of giving rise to $10^{14}$ or more $\mathrm{B}$ cell clones, each synthesizing a unique antibody species with a distinct antigen specificity. In recent years, the molecular basis of this remarkable diversity has become increasingly clear. However, much of this information is derived from studies of the immune response of experimental animals to simple antigens, and it is apparent that significant differences exist among higher vertebrates both in the structure of Ig genes and in mechanisms used to generate diversity. This review will summarize advances in the understanding of the molecular basis for antibody diversity with particular attention to the developmental expression of the antibody repertoire. It will also focus on how molecular analysis of the human antibody response to $\mathrm{Hib}$ may further our understanding of the process by which humans develop a protective immune response.

The human immune response to Hib is an excellent model with which to study the development of the human antibody repertoire. This organism is an important cause of serious bacterial infections, and antibody directed against its capsular polysaccharide protects against invasive infection $(1,2)$. Similar to the response to some other polysaccharide antigens, antibody to Hib polysaccharide develops relatively late in ontogeny. Thus, children less than $5 \mathrm{y}$ of age demonstrate poorer antibody responses to Hib colonization, to infection, and to vaccination with plain Hib polysaccharide vaccine than older children or adults and therefore are most susceptible to infection (2). Coupling Hib polysaccharide to carrier proteins significantly increases immunogenicity of $\mathrm{Hib}$ vaccines (3). In addition to the age-dependent acquisition of anti-Hib polysaccharide antibody, certain ethnic groups and individuals have an increased risk of Hib infection (4-6). It has been hypothesized that both phenom-

Received February 11, 1992; accepted April 30, 1992.

Correspondence and reprint requests: Dr. William L. Carroll, Program in Human Molecular Biology and Genetics, University of Utah, Building 533, Room 3260, Salt Lake City, UT 84112

Supported by the Lattner Foundation, the Allison Hope Hollenbeck Fund, Grant 61 from the March of Dimes, the Markey Center in Molecular Biology of Human Diseases at Washington University, Grant R01-A1 19350 from the National Institutes of Health, a Basil O'Connor Starter Scholar Research Award (W.L.C.), the Medical Research Council of Canada (E.E.A), and Connaught Laboratories (E.E.A). ena may be related to restricted Ig variable region gene usage (7, 8).

\section{PRIMARY Ig GENE DIVERSIFIERS}

Antibody molecules are composed of an identical pair of heavy and light chains, which together create two functional domains $(9,10)$. The constant region is responsible for effector functions such as complement activation and opsonization by attachment to receptors on neutrophils. Ig of the same class or subclass share identical constant regions (e.g. IgM, IgA, IgG). The amino termini of individual heavy and light chains are structurally diverse and are responsible for antigen-antibody interaction. This "variable region" of the molecule is responsible for the molecule's unique antigen specificity. Variable regions of individual heavy and light chains contain three areas of amino acid hypervariability, called CDR, which are principally involved in antigen contact. CDR are separated by "framework" regions, which are highly homologous among individual members of variable region gene families.

The heavy chain variable region locus has been localized to band $14 \mathrm{q} 32.33$ of chromosome 14 (Table 1) (11). The $\kappa$ light chain locus is on the long arm of chromosome 2 . However, a number of functional and nonfunctional $V_{\kappa}$ segments have been found on other chromosomes (22). The $\lambda$ light chain locus is located on chromosome 22 and is the least well characterized (24). Variable regions of heavy and light chain Ig genes are encoded in discontinuous segments along the chromosome (Fig. 1). In the process of forming a functional variable region gene, individual members of two or three groups of "germline" gene segments recombine with one another to form a continuous coding sequence. In the assembly of a heavy chain variable region gene, for example, one of about $30 \mathrm{D}$ segments combines with one of $\operatorname{six} \mathrm{J}_{\mathrm{H}}$ segments and subsequently with one of a larger number (100-300) of $V_{H}$ elements $(13,14,19,20)$. Intervening DNA is usually excised during the recombination process. After a functional heavy chain variable region gene is generated, a light chain variable region gene undergoes similar rearrangement, although D segments are not used (10). Two of the three CDR are encoded by the $V_{H}$ or $V_{\kappa / \lambda}$ segment, whereas the third (CDR3 ) is created by the junction of V, (D), and J segments. Considerable potential exists for the generation of diversity at $V(D) J$ and VJ junctions as a result of both this combinatorial joining of germline segments and other molecular events. For example, the exact joining site between segments may be imprecise due to the action of enzymes removing nucleotides at segment boundaries (exonucleases) and/or the addition of single nucleotides (" $\mathrm{N}$ addition") by terminal deoxynucleotidyl transferase or a similar enzyme $(9,29,30)$. Also, the addition of germlineencoded mono- or dinucleotides has been postulated to occur by " $P$ addition"- the nicking of the terminal 5 ' coding sequence followed by its inversion and joining to $3^{\prime}$ ends of complementary strands (31). These primary diversifiers: combinatorial diversity, junctional diversity, and the pairing of heavy and light 
chains may potentially give rise to a preimmune repertoire of up to $10^{14}$ pre-B lymphocytes with distinct antigen specificities (30).

Recombination of $\mathrm{V}, \mathrm{D}$, and $\mathbf{J}$ segments appears to be mediated by enzymes found only in lymphoid cells, which are active at discrete stages in maturing B cells. These enzymes are targeted to recombination signal sequences that flank $\mathrm{V}, \mathrm{D}$, and $\mathbf{J}$ segments. These sequences are composed of conserved segments of 7 and 9 bp separated by a spacer of 12 or $23 \mathrm{bp} \mathrm{(10).} \mathrm{The}$ recombination signal sequence of a light chain chain $V_{k}$ or $V_{\lambda}$ segment binds to complementary nucleotides adjacent to the $J_{K}$ or $\mathbf{J}_{\lambda}$ in light chain variable region genes, bringing the two segments into juxtaposition. A similar strategy is used in the recombination of heavy chain genes, with DJ rearrangement preceding $\mathrm{V}$ to $\mathrm{DJ}$ recombination.

The enzymes responsible for Ig gene rearrangement are not fully characterized. A number of proteins are likely to participate in recombination signal recognition, site-specific DNA cleavage, nucleotide addition and deletion at segment boundaries, and ligation of segment junctions. It appears that identical or very similar enzymes rearrange $T$ cell receptor genes in developing $T$ cells (32). Two closely linked "recombination activating" genes, RAG-1 and RAG-2, have been isolated and shown to synergistically activate $\mathrm{V}(\mathrm{D}) \mathrm{J}$ recombination $(33,34)$. Both genes are highly conserved between mice and humans, and are expressed concordantly only in pre-B and pre-T cells. The proteins encoded by these genes are not structurally similar to one another, and the exact role they play in the recombination process remains to be elucidated. They may comprise distinct subunits of a "recombinase" complex or may act at different steps in the recombina-

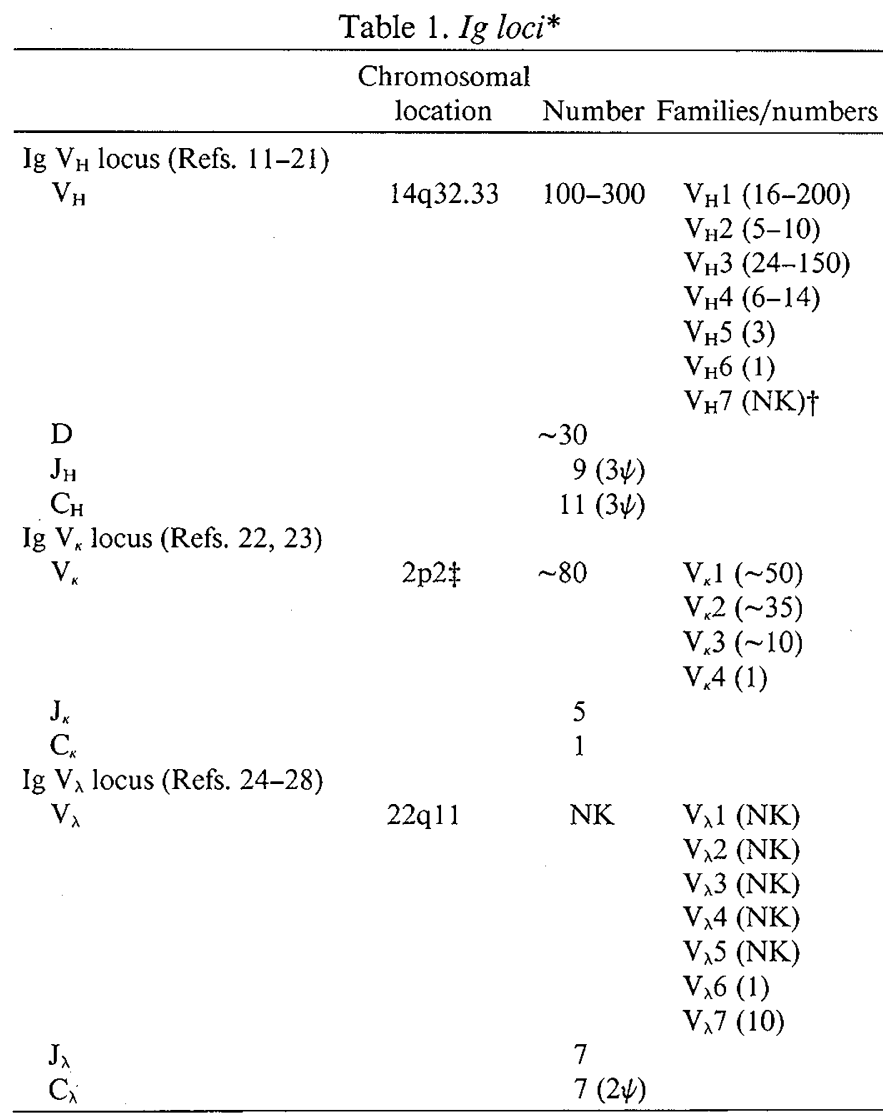

* Columns show members of the three Ig linkage groups, chromosomal location of Ig loci, total estimated number of $\mathrm{V}$ (variable), D (heavy chain diversity), $\mathrm{J}$ (joining), and $\mathrm{C}$ (constant region) elements in each group ( $\psi$ indicates pseudogenes), known variable region families, and estimated number of variable region family members.

$\uparrow \mathrm{NK}$, not known.

$\ddagger$ Twenty-five to 40 "orphan" $V_{\kappa}$ segments are located outside the $\kappa$ locus. tion pathway. Another enzyme, the murine $J_{\kappa}$ recombination signal-binding protein, may play an important role in $V(D) J$ rearrangement, based on its binding specificity and structural similarity to the integrase family of microbial recombinases $(35$, 36).

\section{SECONDARY Ig GENE DIVERSIFIERS}

Further "second order" diversification of variable regions can occur even after V(D)J rearrangement is complete. After a functional $\mathrm{V}(\mathrm{D}) \mathrm{J}$ rearrangement occurs on one chromosome, recombination on the other usually is silenced, a property referred to as "allelic exclusion." However, we and others have demonstrated new $\mathrm{V}$ to (D)J recombination at both light and heavy chain loci after an initial rearrangement event (37-39). Such V segment replacement can occur independently on both alleles and may lead to the expression of new antigen binding domains. In heavy chain variable region genes, an upstream $V_{H}$ segment recombines with the existing rearrangement at a seven-nucleotide sequence near the $3^{\prime}$ end of the original $V_{H}$ segment, thus preserving the initial DJ rearrangement (37). Ongoing rearrangement of the light chain loci allows an upstream $V$ segment to recombine with a downstream $J$ segment, thereby replacing the original rearrangement entirely $(38,39)$. The extent to which this process contributes to the generation of antibody diversity in vivo is uncertain.

Somatic hypermutation of variable region genes contributes substantially to the maturation of the mammalian B cell immune response $(10,40)$. Ig mutation rates approach one mutation per thousand bases in each cycle of cell replication, at least $10000-$ fold greater than the spontaneous mutation rate for other eukaryotic genes (41). Single base substitutions predominate and occur in both productively and nonproductively rearranged genes (4246). This hypermutation is tightly focused to the rearranged $\mathrm{V}(\mathrm{D}) \mathrm{J}$ segment and immediate flanking regions $(47,48)$. The onset of hypermutation appears to occur after contact with antigen (49). Substitutions that result in greater antigen affinity are selected for during the late primary and secondary immune response, a phenomenon known as "affinity maturation."

B lymphocyte malignancies represent cells arrested at discrete stages of development and are useful models to study Ig gene diversification. Extensive variable region gene mutation has been demonstrated within the cells of human follicular lymphoma (surface Ig-positive cells with morphologic characteristics of germinal center lymphocytes) $(50,51)$, but not pre-B acute lymphocytic leukemia, sporadic Burkitt's lymphoma, or chronic lymphocytic leukemia (52-54). This suggests that Ig hypermutation is activated at a well-defined stage in B cell development. Also, ongoing hypermutation has been demonstrated in the variable region genes of murine $\mathrm{B}$ cells isolated from individual germinal centers $(55,56)$. Positive selection of germinal center lymphocytes with high affinity for antigen bound to follicular dendritic cells may result in their differentiation into memory cells or plasma cells. Conversely, B cells whose mutated variable region genes have lower affinity for antigen appear to be removed by a process termed apoptotic cell death (57).

Although several mechanisms for Ig hypermutation have been proposed, two general models have received the most support and prompted the most investigation: 1 ) repair of variable region genes by an error-prone DNA polymerase $(43,58)$ and 2 ) errorprone replication $(59,60)$. We have found no evidence of errorprone repair in human lymphoid cell lines representing intermediate stages in B cell development (61), although VallesAyoub et al. (62) demonstrated altered repair efficiency in germinal center B cells of human tonsils. Rogerson et al. (60) have recently developed a replicative model of hypermutation in the mouse, postulating the transient presence in mutating $B$ cells of a factor characterized by high affinity for a putative "mutation initiation region" located upstream of variable region gene pro- 

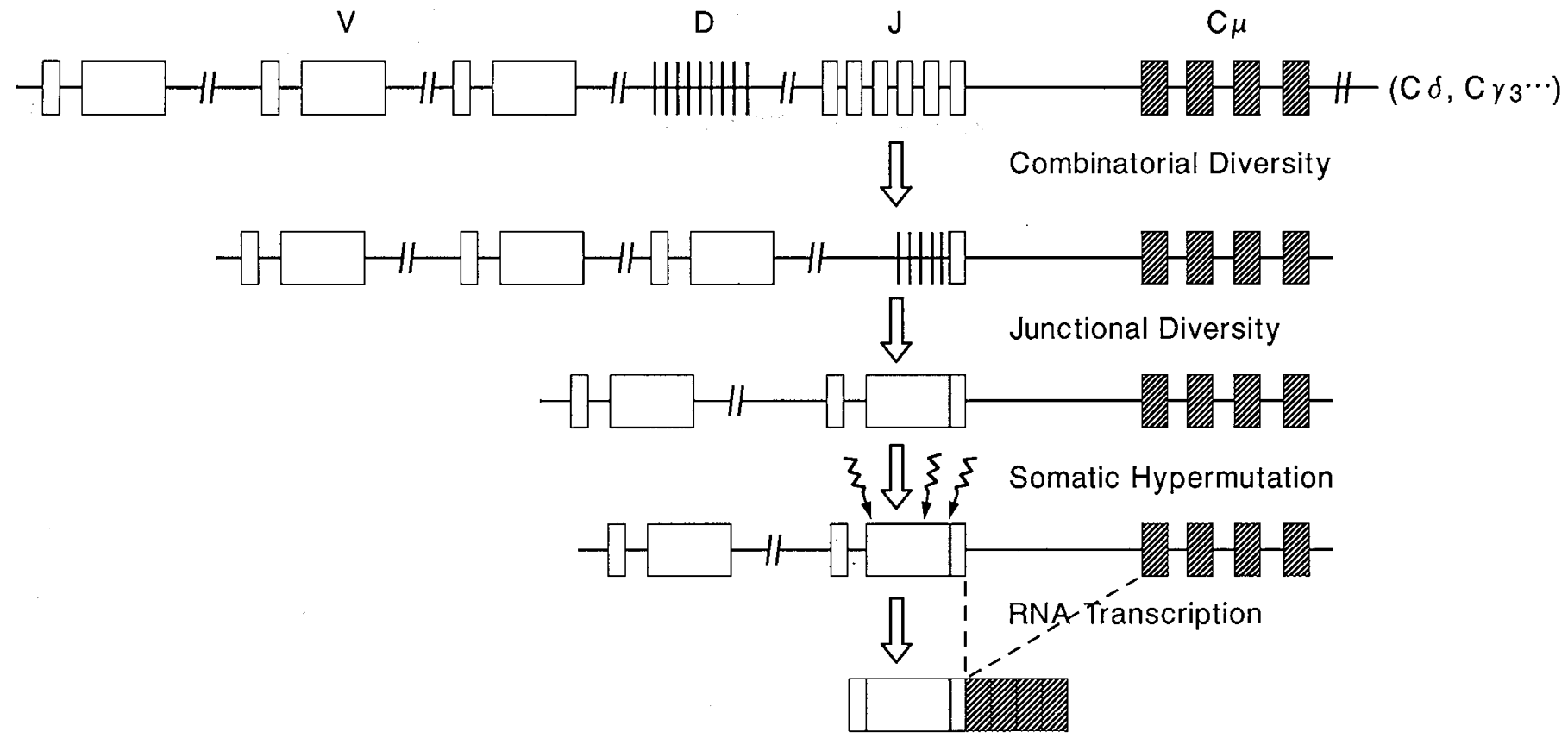

Fig. 1. Rearrangement of an $\mathrm{Ig} \mathrm{V}_{\mathrm{H}}$ gene. During the process of recombination, one of about $30 \mathrm{D}$ segments is joined to one of six $\mathrm{J}_{\mathrm{H}}$ segments, and subsequently to one of $100-300 \mathrm{~V}_{\mathrm{H}}$ segments. Intervening DNA between recombined segments is usually excised but may be retained if individual segments are in opposite transcriptional orientation to one another. Rearranged $\mathrm{Ig} \mathrm{V}_{\mathrm{H}}$ genes may be further diversified by somatic hypermutation.

moters and by dependence upon an active upstream origin of replication.

\section{STRUCTURAL ORGANIZATION OF Ig GENES IN HIGHER ORGANISMS}

Although a substantial amount of information is available regarding the molecular mechanisms of antibody gene diversity, the relative contributions of individual molecular diversifiers to the final makeup of the human immune response to a specific antigen is unknown. The overall structure of human heavy and light chain Ig loci has not been completely characterized. The heavy chain locus is estimated to contain up to $300 \mathrm{~V}_{\mathrm{H}}$ segments, divided into six or seven families on the basis of $>80 \%$ nucleic acid sequence homology (Table 1) $(13,63)$. Members of individual families are interspersed rather than being grouped together on the chromosome (12). The $\kappa$ light chain variable region gene locus is estimated to contain about 50 functional $V_{\kappa}$ genes composing four families (22). A large portion of the locus is duplicated and a small number of $V_{K}$ genes are not located in association with the $\mathrm{J}_{\kappa}$ segments and $\kappa$ light chain constant region gene segments on chromosome $2(64-66)$. The human $\lambda$ light chain variable region gene locus is less well characterized but appears more complex than that of the mouse, with an unknown number of $V_{\lambda}$ segments belonging to seven families (25).

Although the structural organization of Ig loci is generally similar in vertebrate species, important differences exist and, further, each species appears to rely on alternative molecular mechanisms to diversify its antibody repertoire. The murine heavy chain variable region gene locus is estimated to contain a larger number of $\mathrm{V}_{\mathrm{H}}$ segments than the human locus (up to 1000 or more germline elements) and, in contrast to the highly interspersed rearrangement of human $V_{H}$ gene families, members of murine families are clustered together $(12,67,68)$. Despite these differences, the generation of antibody diversity in mice may most closely resemble that of humans (10). In contrast, although several hundred $\mathrm{V}_{\mathrm{H}}$ gene segments are present in the rabbit heavy chain variable region gene locus, $80-90 \%$ of expressed antibody is encoded by a single $\mathrm{V}_{\mathrm{H}}$ gene segment and diversity in rabbit heavy chain variable region genes appears to be generated largely by secondary diversifiers (somatic mutation and gene conversion) (69). The chicken $\lambda$ light chain variable region gene locus is composed of a single functional $\mathrm{V}_{\lambda}$ gene and 25 nonfunctional "pseudogenes." Only the functional segment is rearranged initially, and diversification is achieved subsequently through gene conversion, with pseudogenes providing donor sequences (70). These species-specific differences emphasize the importance of using a human model to examine the development of human specific immunity.

\section{DEVELOPMENTALLY RESTRICTED Ig GENE DIVERSIFICATION}

Although the structure of Ig loci and recombinatorial mechanisms theoretically may yield an almost unlimited number of Ig molecules, considerable constraints may be placed on the use of variable region gene segments during development. In both mice and humans, a small group of $\mathrm{V}_{\mathrm{H}}$ genes is preferentially expressed in early development (71-76). In mice, preferential use of certain $\mathrm{V}_{\mathrm{H}}$ genes is related in part to their location proximal to the $J_{H}$ segment on the chromosome. The most $\mathrm{J}_{\mathrm{H}}$-proximal members of the human $V_{H}$ locus are the single member of the $V_{H} 6$ gene family, a $\mathrm{V}_{\mathrm{H}} 4$ and a $\mathrm{V}_{\mathrm{H}} 2$ segment, and several $\mathrm{V}_{\mathrm{H}} 1$ gene family members $(17,71,77,78) . \mathrm{V}_{\mathrm{H}} 6$ and $\mathrm{V}_{\mathrm{H}} 2$ gene segments are among those preferentially expressed in the human fetus, perhaps disproportionately so in view of the small size of these families (76). Over $60 \%$ of "fetal" transcripts, however, are encoded by $\mathrm{V}_{\mathrm{H}} 3$ genes, which are not among the most $3^{\prime} \mathrm{V}_{\mathrm{H}}$ segments. Further, $\mathrm{V}_{\mathrm{H}} 5$ genes may also be over-represented in the early fetal repertoire and, again, are not among the most $\mathrm{J}_{\mathrm{H}}$-proximal $\mathrm{V}_{\mathrm{H}}$ segments $(17,75-78)$. Thus, mechanisms other than geographic location within the heavy chain variable region gene locus are likely to play a role in preferential use of human $V_{H}$ genes in fetal development. Disproportionately frequent expression of some murine $V_{\kappa}$ families has been observed in both fetal $B$ cells and in adult mice, suggesting that constraints on $V_{\kappa}$ segment use may persist beyond the neonatal period $(79,80)$. In mice there is evidence that preferential expression of certain $V_{H}$ gene family members is related to the regulated expression of these segments by different B cell subpopulations (81). 
The use of junctional diversifiers may also be developmentally regulated. In humans, expression of diversity gene segments appears to differ with age, with preferential use of DHQ52 or DXP families in early development and more stochastic usage in adults $(19,30,76,82)$. $\mathrm{J}_{\mathrm{H}}$ segment use may also differ, with $\mathrm{J}_{\mathrm{H}} 3$ and $\mathrm{J}_{\mathrm{H}} 4$ segments predominating in fetal and $\mathrm{J}_{\mathrm{H}} 4$ and $\mathrm{J}_{\mathrm{H}} 6$ in adult $\mathrm{B}$ cell populations $(76,82)$. $\mathrm{N}$ addition is absent in murine fetal B cells and increases with time. A similar increase in the frequency of $\mathrm{N}$ and $\mathrm{P}$ insertions with age is observed in murine $\gamma \delta \mathrm{T}$ cell receptors $(31,83)$. The average length of human fetal and neonatal CDR-3 regions is shorter than that of adults, independent of $\mathrm{N}$ addition (30).

These developmental constraints on variable region gene use may have important implications for the maturation of the immune response. In mice, the antibody response to certain antigens appears in a well-defined temporal pattern that is highly conserved among different murine strains $(84,85)$. A similar pattern of responsiveness exists in humans, with the appearance of antibodies to protein antigens in the first several months of life followed later by the acquisition of the ability to produce protective levels of antibody directed against carbohydrate antigens at $12 \mathrm{mo}$ of age or older (86). Additionally, each individual appears to generate anticarbohydrate antibodies from a limited number of $\mathrm{B}$ cell clones and, in contrast to antibody directed against protein antigens, these antibodies are not characterized by extensive somatic hypermutation $(7,8,87)$. Programmed changes in variable region gene use and other diversifiers described above may explain the age-related acquisition of specific immunity.

\section{ANTIBODY RESPONSE TO Hib}

To examine variable region gene use during the human immune response to Hib polysaccharide, we have generated from immunized subjects a panel of hybridomas that secrete monoclonal human antibodies specific for this antigen. The polymerase chain reaction was used to clone variable region genes from these cell lines $(7,8)$ (Table 2). The most striking feature of this immune response is the degree of restriction evident in both heavy and light chain variable region gene use. The majority of heavy chain variable region genes encoding anti-Hib polysaccharide antibodies are members of the $\mathrm{V}_{\mathrm{H}} 3$ gene family. All antiHib polysaccharide $V_{H}$ genes sequenced to date are members of the $\mathrm{V}_{\mathrm{H}} 3$ gene family (7). However, serologic analysis indicates that some individuals also express a small portion of antibodies encoded by $V_{H} 1$ or $V_{H} 4$ family members after immunization (92). We have obtained 11 heavy chain variable region genes from a total of nine subjects (unpublished manuscript) (Fig. 2).
All these $\mathrm{V}_{\mathrm{H}}$ segments are encoded by members of the $\mathrm{V}_{\mathrm{H}} 3$ gene family, and eight are members of the smaller $V_{H} 3 b$ subfamily. The $V_{\mathrm{H}}$ gene segments are $70-100 \%$ homologous to one another, and also highly homologous to two candidate germline $\mathrm{V}_{\mathrm{H}} 3$ genes. The high homology shared by hybridoma gene segments and close identity with unrearranged germline genes suggests that these genes are derived from a very small subset of the total available $V_{H}$ repertoire. Although these antibodies are likely to represent a secondary immune response and subjects were immunized with either "T-independent" plain Hib polysaccharide or "T-dependent" polysaccharide-protein conjugate vaccines, somatic mutation appears to be infrequent in many of these heavy chain variable region genes. Interestingly, the anti-Hib polysaccharide heavy chain variable region gene segments are highly homologous to segments preferentially expressed in the fetus and to those encoding autoantibodies $(75,76,93,94)$.

At least four $V_{\kappa}$ and two $V_{\lambda}$ gene families encode anti-Hib polysaccharide light chain variable region genes $(8,89,95)$. A large proportion of these antibodies, however, as in the heavy chain variable region response, appear to be encoded by a limited number of germline elements. Approximately $60 \%$ of serum antibody of older children and adults is encoded by a single $\mathrm{V}_{k} \mathrm{II}$ gene, A2, and at least a portion of these antibodies are encoded in an unmutated form, irrespective of antigen presentation as plain polysaccharide or polysaccharide-protein conjugate form $(8,89,96)$. The majority of $\lambda$ anti-Hib polysaccharide antibody cross-reacts with the structurally related antigen Escherichia coli K100 polysaccharide, and gastrointestinal colonization with this bacteria may induce protective anti-Hib polysaccharide antibodies before exposure to Hib itself $(97,98)$. E. coli K100 crossreactivity of $\lambda$ anti-Hib polysaccharide antibody also appears to be mediated by a single germline $V_{\lambda}$ VII element (8). The paucity of sequence differences in $V_{\lambda}$ VII segments obtained from four unrelated subjects suggests that these genes also are relatively unmutated.

CDR-3 regions of both heavy and light chain variable region genes, created by VDJ and VJ joints, respectively, also appear to be relatively restricted. Although a variety of $D$ and $J$ segments are used, preferential use of certain DJ combinations is seen and some heavy chain variable regions, obtained from unrelated individuals, share identical VDJ joints (unpublished manuscript). VJ joints of the majority of anti-Hib polysaccharide antibody light chain variable region genes, including all $\lambda$ antibodies and the predominant $\mathrm{V}_{\kappa} \mathrm{II}$ A2-encoded $\kappa$ antibodies, are notable for the presence of an arginine residue. In at least some of these antibodies, this residue must have arisen by $\mathrm{N}$ addition, an uncommon event in light chain variable region gene rearrangement $(8,89)$.

Table 2. Hybridoma cell lines*

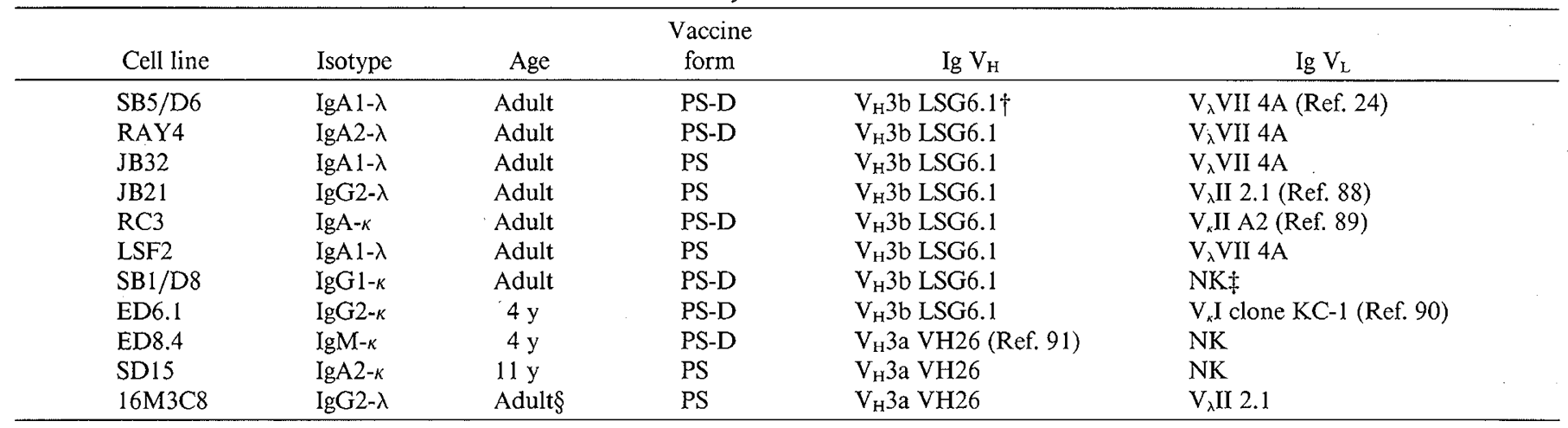

* Columns show name of hybridoma cell line, isotype of secreted anti-Hib polysaccharide antibody, age of subject at immunization, vaccine formulation (PS is plain polysaccharide, PS-D is Hib PS covalently linked to diphtheria toxoid), and most closely homologous germline $V_{H}$ and $V_{k} /$ $V_{\lambda}$ segments identified. Ig $V_{L}$, light chain variable region Ig.

$\dagger$ Manuscript submitted for publication. This sequence is identical to the cDNA clone M85 reported by Schroeder and Wang (76).

$\ddagger \mathrm{NK}$, not known.

$\S$ Pool of three adult donors. 

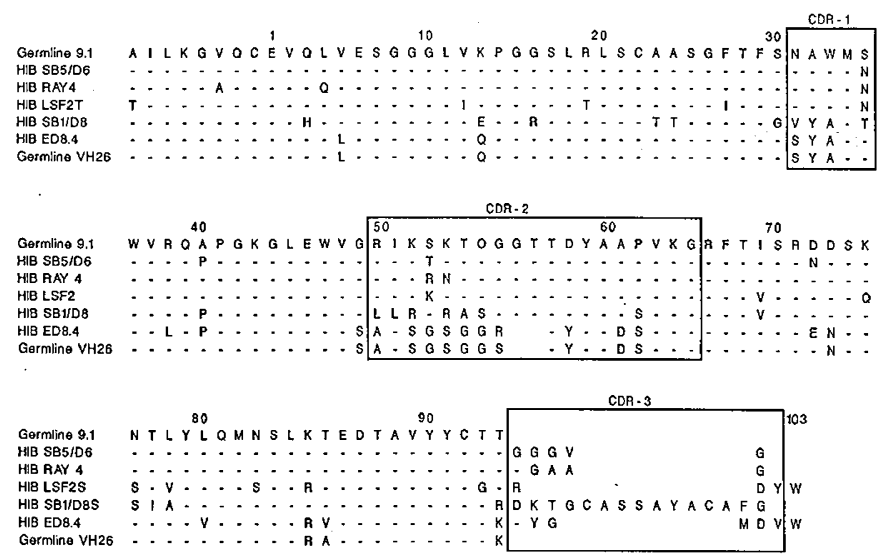

Fig. 2. Anti-Hib polysaccharide $\operatorname{Ig} V_{H}$ genes. Shown are the translated amino acid sequences of five anti-Hib polysaccharide specific $I g \mathrm{~V}_{\mathrm{H}}$ genes and, for comparison, the translated amino acid sequences of two candidate germline genes, 9.1 (13) and $V_{H} 26(92)$. CDR are boxed. Sequences illustrate the high homology of hybridoma $V_{H}$ sequences and the differences produced within CDR-3 regions by combinatorial and junctional diversifiers. [From Adderson et al. (7), with permission.]

The restriction in both heavy and light chain variable region genes may explain the poor response to Hib vaccines and the increased incidence of invasive Hib disease in some individuals and ethnic groups. These subjects may lack one or more of these important gene segments, leading to the inability to produce antibody of optimal affinity or specificity. An individual with a deletion of the germline gene encoding the predominant $\kappa$ light chain has been described. This individual produced anti-Hib polysaccharide antibody with other less commonly expressed light chains (89). In the more restricted heavy chain variable region gene response, it may not be possible to rely on alternative germline elements in the event of such a genetic polymorphism.

Although the $\mathrm{V}_{\mathrm{H}}$ gene segments that appear most likely to be used in the anti-Hib polysaccharide antibody response are known to be expressed in the fetus, variable region gene use in the developing infant has not been closely studied. Polysaccharideprotein conjugate $\mathrm{Hib}$ vaccines are capable of eliciting antibody in children as young as 2 mo of age. These infants appear to use the $V_{k} I I$ gene segment encoding the predominant $\kappa$ light chains identified in older subjects (96). Whether these antibodies are produced by an alternative $B$ cell subset or whether $B$ cells specific for Hib polysaccharide are relatively less responsive to plain polysaccharide antigen compared to $\mathrm{T}$-dependent antigen formulations in early development is the subject of ongoing investigation.

Although significant progress has been made in understanding the molecular basis of antibody diversity, major questions still remain unanswered. Current research is focused on identification of the recombinase complex responsible for Ig gene rearrangement and the understanding of selective gene segment use both in individual $B$ cell subsets and in different developmental stages of humans and other organisms. The molecular basis of somatic hypermutation, which is responsible for affinity maturation of the immune response, remains to be elucidated. Finally, the clinical impact of variable region gene deletion or polymorphisms on the development of the normal immune response and on disorders of immunodeficiency, autoimmunity, and malignancy is an active area of contemporary immunologic research (reviewed in Refs. 99-102).

Acknowledgments. The authors thank Dr. Harvey R. Colten for his support and encouragement and Drs. Stephen M. Prescott, Richard T. O'Brien, and Michael A. Simmons for their critical review of the manuscript.

\section{REFERENCES}

1. Robbins JB, Parks JC, Schneerson R, Whishart JK 1973 Quantitative measurement of "natural" and immunization induced Haemophilus influenzae type b capsular antibodies. Pediatr Res 7:103-110

2. Peltola H, Kayhty H, Virtanen M, Makela PH 1984 Prevention of Haemophilus influenzae type $\mathrm{b}$ bacterial infections with the capsular polysaccharide vaccine. N Engl J Med 310:1561-1565

3. Kayhty H, Peltola H, Eskola J, Ronnberg P, Kela E, Karanko V, Makela PH 1989 Immunogenicity of Haemophilus influenzae oligosaccharide-protein conjugate and polysaccharide-protein conjugate vaccine in children at 4,6 , and 14 months of age. Pediatrics 84:995-999

4. Ward JJ, Margolis HS, Lum MK, Fraser DW, Bender TR 1981 Haemophilus influenzae disease in Alaskan Eskimos: characteristics of a population with an unusual incidence of invasive disease. Lancet 1:1281-1285

5. Coulehan JL, Michaels RH, Hallowell C, Schults R, Welty TK, Kuo JSC 1984 Epidemiology of Haemophilus influenzae type b disease among Navajo indians. Public Health Rep 99:404-409

6. Granoff DM, Sheetz KE, Nahm MH, Madassery JV, Shackelford PG 1988 Further immunologic evaluation of children who develop Haemophilus disease despite previous vaccination with type $b$ polysaccharide vaccine. Monogr Allergy 23:256-268

7. Adderson EE, Shackelford PG, Quinn A, Carroll WL 1991 Restricted Ig heavy chain $\mathrm{V}$ gene usage in the human antibody response to Haemophilus influenzae type $\mathrm{b}$ capsular polysaccharide. J Immunol 147:1667-1674

8. Adderson EE, Shackelford PG, Insel RA, Quinn A, Wilson PM, Carroll WL 1992 Immunoglobulin light chain variable region gene sequences for human antibodies to Haemophilus influenzae type b capsular polysaccharide are dominated by a limited number of $V_{x}$ and $V$ segment and VJ combinations. J Clin Invest 89:729-738

9. Alt FW, Blackwell TK, Yancopoulos GD 1987 Development of the primary antibody repertoire. Science 238:1079-1087

10. Tonegawa S 1983 Somatic generation of antibody diversity. Nature 302: $575-581$

11. Cox DW, Markovic VD, Teshima IE 1982 Genes for immunoglobulin heavy chains and for $\alpha 1$-antitrypsin and localized to specific regions of chromosome 14q. Nature 297:428-430

12. Kodaira M, Kinashi T, Umemura I, Matsuda $F$, Noma $T$, Ono $Y$, Honjo $T$ 1986 Organization and evolution of variable region genes of the human immunoglobulin heavy chain. J Mol Biol 190:529-541

13. Berman JE, Mellis SJ, Pollack R, Smith CL, Suh H, Heinke B, Kowal C, Surti U, Chess L, Cantor CR, Alt FW 1988 Content and organization of the human $\mathrm{Ig} \mathrm{V}_{\mathrm{H}}$ locus: definition of three new $\mathrm{V}_{\mathrm{H}}$ families and linkage to the Ig $\mathrm{C}_{\mathrm{H}}$ locus. EMBO J 7:727-738

14. Schroeder HW, Walter MA, Hofker MH, Ebers A, Willems van Dijk K, Liao LC, Cox DW, Milner ECB, Perlmutter RM 1988 Physical linkage of a human immunoglobulin heavy chain variable region gene segment to diversity and joining segments. Proc Natl Acad Sci USA 85:8196-8200

15. Walter MA, Surti U, Hofker MH, Cox DW 1990 The physical organization of the human immunoglobulin heavy chain gene complex. EMBO J 9: 3303-3313

16. Walter MA, Dosch HM, Cox DW 1991 A deletion map of the human immunoglobulin heavy chain variable region. J Exp Med 174:335-349

17. Shin EK, Matsuda F, Nagaoka H, Fukita Y, Imai T, Yokoyama K, Soeda E, Honjo T 1991 Physical map of the 3' region of the human immunoglobulin heavy chain locus: clustering of autoantibody-related variable segments in one haplotype. ЕMBO J 10:3641-3645

18. Siebenlist U, Ravetch JV, Korsmeyer S, Waldmann T, Leder P 1981 Human immunoglobulin D segments encoded in tandem multigene families. Nature 294:631-635

19. Ichihara Y, Matsuoka H, Kurosawa Y 1988 Organization of human immunoglobulin heavy chain diversity gene loci. EMBO J 7:4140-4150

20. Ravetch JV, Siebenlist U, Korsmeyer S, Waldmann T, Leder P 1981 Structure of the human immunoglobulin $\mu$ locus: characterization of embryonic and rearranged $J$ and $D$ genes. Cell 27:583-591

21. Matsuda $F$, Lee $K H$, Nakai S, Sato $T$, Kodaira $M$, Zong SQ, Ohno $H$, Fukuhara S, Honjo T 1988 Dispersed localization of D segments in the human immunoglobulin heavy-chain locus. EMBO J 7:1047-1051

22. Meindl A, Klobeck H-G, Ohnheiser R, Zachau HG 1990 The $V_{\kappa}$ gene repertoire in the human germline. Eur J Immunol 20:1855-1863

23. Hieter PA, Max EE, Seidman JG, Maizel JG, Leder P 1980 Cloned human and mouse kappa immunoglobulin constant and $\mathrm{J}$ region genes conserve homology in functional segments. Cell 22:197-207

24. Anderson MLM, Szajnert MF, Kaplan JC, McColl L, Young BD 1984 The isolation of a human $\mathrm{IgV}_{\lambda}$ gene from a recombinant library of chromosome 22 and estimation of the copy number. Nucleic Acids Res 12:6647-6660

25. Chuchana P, Blancher A, Brockly F, Alexandre D, Lefranc G, Lefranc M-P 1990 Definition of the human immunoglobulin variable lambda (IGLV) gene subgroups. Eur J Immunol 20:1317-1325

26. Udey JA, Blomberg B 1987 Human $\lambda$ light chain locus: organization and DNA sequences of three genomic $J$ regions. Immunogenetics 25:63-70

27. Chang H, Dmitrovsky E, Heiter PA, Mitchell K, Leder P, Truoczi L, Kirsch IR, Hollis GF 1986 Identification of three new Ig $\lambda$-like genes in man. J Exp Med 163:425-435

28. Hieter PA, Hollis GF, Korsmeyer SJ, Waldmann TA, Leder P 1981 Clustered arrangement of immunoglobulin $\lambda$ constant region genes in man. Nature 294:536-540

29. Desiderio SV, Yancopoulos GD, Paskind M, Thomas E, Boss MA, Landau 
$\mathrm{N}$, Alt FW, Baltimore D 1984 Insertion of N regions into heavy chain genes is correlated with expression of terminal deoxytransferase in B cells. Nature 311:752-755

30. Sanz I 1991 Multiple mechanisms participate in the generation of diversity of human H chain CDR3 regions. J Immunol 147:1720-1729

31. Lafaille JJ, DeCloux A, Bonneville M, Takagaki Y, Tonegawa S 1989 Junctional sequences of $\mathrm{T}$ cell receptor $\gamma \delta$ genes: implications for $\gamma \delta \mathrm{T}$ cell lineages and for a novel intermediate of V-(D)-J joining. Cell 59:859-870

32. Yancopoulos GD, Blackwell TK, Suh H, Hood L, Alt FW 1986 Introduced $T$ cell receptor variable gene segments recombine in pre-B cells: evidence that $B$ and $T$ cells use a common recombinase. Cell 44:251-259

33. Schatz D, Oettinger M, Baltimore D 1989 The V(D)J recombination activating gene, RAG-1. Cell 59:1035-1048

34. Oettinger M, Schatz D, Gorka C, Baltimore D 1990 RAG-1 and RAG-2, adjacent genes that synergistically activate $V(D) J$ recombination. Science 248:1517-1523

35. Matsunami N, Hamaguchi $Y$, Yamamoto $Y$, Kuze K, Kangawa K, Matsuo $H$, Kawaichi M, Honjo T 1989 A protein binding to the $J_{\kappa}$ recombination sequence of immunoglobulin genes contains a sequence related to the integrase motif. Nature 342:934-937

36. Hamaguchi Y, Matsunami N, Yamamoto Y, Honjo T 1989 Purification and characterization of a protein that binds to the recombination signal sequence of the immunoglobulin $\mathbf{J}$ kappa segment. Nucleic Acids Res 17: 9015-9026

37. Kleinfield R, Hardy R, Tarlinton D, Dangl J, Herzenberg L, Weigert M 1986 Recombination between an expressed immunoglobulin heavy-chain gene and a germline variable gene segment in a $\mathrm{Ly}^{+} \mathrm{B}$-cell lymphoma. Nature 322:843-846

38. Carroll WL, Starnes C, Levy R, Levy S 1988 Alternative $V_{\kappa}$ gene rearrangements in a murine B cell lymphoma. J Exp Med 168:1606-1620

39. Levy S, Campbell M, Levy R 1989 Functional immunoglobulin light chain genes are replaced by ongoing rearrangements of germline $V_{\kappa}$ genes to downstream $J_{\kappa}$ segments in a murine B cell line. J Exp Med 170:1-13

40. Baltimore D 1981 Somatic mutation gains its place among the generators of diversity. Cell 26:295-296

41. McKean D, Hüppi K, Bell M, Staudt L, Gerard W, Weigert M 1984 Generation of antibody diversity in the immune response of BALB/c mice to influenza virus hemagglutinin. Proc Natl Acad Sci USA 81:3180-3184

42. Siekevitz M, Kocks C, Rajewsky K, Dildrop R 1987 Analysis of somatic mutation and class switching in naive and memory $B$ cells generating adoptive primary and secondary responses. Cell 48:757-770

43. Levy N, Malipiero U, LeBecque S, Gearhart P 1989 Early onset of somatic mutation in immunoglobulin $\mathrm{V}_{\mathrm{H}}$ genes during the primary immune response. J Exp Med 169:2007-2019

44. Gearhart P, Bogenhagen D 1983 Clusters of point mutations are found exclusively around rearranged antibody variable regions. Proc Natl Acad Sci USA 80:3439-3453

45. Roes J, Hüppi K, Rajewsky K, Sablitzky F 1989 V gene rearrangement is required to fully activate the hypermutation mechanism in $\mathrm{B}$ cells. $\mathrm{J}$ Immunol 142:1022-1026

46. Both G, Taylor L, Pollard J, Steele E 1990 Distribution of mutations around rearranged heavy-chain antibody variable-region genes. Mol Cell Biol 10: $5187-5196$

47. Gorski J, Rollini P, Mach B 1983 Somatic mutations of immunoglobulin variable region are restricted to the rearranged $V$ gene. Science 220 : $1179-1182$

48. Sablitzky F, Weisbaum D, Rajewsky K 1985 Sequence analysis of nonexpressed immunoglobulin heavy chain loci in clonally related, somatically mutated hybridoma cells. EMBO J 4:3435-3442

49. Berek C, Griffiths G, Milstein C 1985 Molecular events during maturation of the immune response to oxazolone. Nature 316:412-416

50. Cleary M, Meeker T, Levy S, Lee E, Trela M, Sklar J, Levy R 1986 Clustering of extensive somatic mutations in the variable region of an immunoglobulin heavy chain from a human B cell lymphoma. Cell 44:97-106

51. Carroll WL, Lowder JN, Streifer R, Warnke R, Levy S, Levy R 1986 Idiotype variant cell populations in patients with $B$ cell lymphoma. J Exp Med 164: $1566-1580$

52. Bird J, Galili N, Link M, Stites D, Sklar J 1989 Continuing rearrangement but absence of somatic hypermutation in immunoglobulin genes of human B cell precursor leukemia. J Exp Med 168:229-238

53. Carroll W, Yu M, Link M, Korsmeyer S 1989 Absence of Ig V region gene somatic hypermutation in advanced Burkitt's lymphoma. J Immunol 143: 692-698

54. Kipps T, Tomhave E, Chen P, Carson D 1988 Autoantibody-associated $k$ light chain variable region gene expressed in chronic lymphocytic leukemia with little or no somatic mutation. J Exp Med 167:840-851

55. Jacob J, Kelsoe G, Rajewsky K, Weiss U 1991 Intraclonal generation of antibody mutants in germinal centres. Nature 354:389-392

56. Berek C, Berger A, Apel M 1991 Maturation of the immune response in germinal centers. Cell 67:1121-1129

57. MacLennan I 1991 The centre of hypermutation. Nature 354:352-353

58. Brenner S, Milstein C 1966 Origin of antibody variation. Nature 211: 242-247

59. Manser T 1990 The efficiency of antibody affinity maturation: can the rate of B-cell division be limiting? Immunol Today 11:305-308

60. Rogerson B, Hackett J, Peters A, Haasch D, Storb U 1991 Mutation pattern of immunoglobulin genes is compatible with a model of somatic hyper- mutation in which targeting of the mutator is linked to the direction of DNA replication. EMBO J 10:4331-4341

61. Johnston J, Yu M, Carroll W 1992 A shuttle vector system for the investigation of immunoglobulin gene hypermutation: absence of enhanced mutability in B lymphoid cell lines. Mol Immunol (in press)

62. Valles-Ayoub Y, Govan HL, Braun J 1991 Immunoglobulin variable region hypermutation is associated with a DNA repair deficit. FASEB $\mathrm{J}$ 5: A604(abstr)

63. Newton JA, Mortarti FM, Schaffer PM, Kirkham PM, Wang JY, Schroeder HW 1991 Characterization of a new immunoglobulin VH family which is preferentially utilized in cord blood. Pediatr Res 29:276A(abstr)

64. Klobeck H-G, Meindl A, Combriato G, Solomon A, Zachau HG 1985 Human immunoglobulin kappa light chain genes of subgroups II and III. Nucleic Acids Res 13:6499-6513

65. Klobeck H-G, Bornkamm GW, Combriato G, Mocikat R, Pohlenz H-D, Zachau HG 1985 Subgroup IV of human immunoglobulin $\kappa$ light chains is encoded by a single germline gene. Nucleic Acids Res 13:6515-6529

66. Straubringen B, Huber E, Lorenz W, Osterholzer E, Pargent W, Pech M, Pohlenz H-D, Zimmer F-J, Zachau HG 1988 The human V $V_{x}$ locus. Characterization of a duplicated region encoding 28 different immunoglobulin genes. J Mol Biol 199:23-34

67. Livant D, Blatt C, Hood L 1986 One heavy chain variable region gene segment subfamily in the $\mathrm{BALB} / \mathrm{c}$ mouse contains $500-1000$ or more members. Cell 47:461-470

68. Kemp DJ, Tyler B, Bernard O, Gough N, Gerondakis S, Adams JM, Cory S 1981 Organization of genes and spacers within the mouse immunoglobulin $\mathrm{V}_{\mathrm{H}}$ locus. J Mol Appl Genet 1:245-261

69. Knight KL, Becker RS 1990 Molecular basis of the allelic inheritance of rabbit immunoglobulin $\mathrm{V}_{\mathrm{H}}$ allotypes: implications for the generation of antibody diversity. Cell 60:963-970

70. Weill J-C, Reynaud C-A 1987 The chicken B cell compartment. Science 238: 1094-1098

71. Yancopoulos GD, Desiderio SV, Paskind M, Kearney JF, Baltimore D, Alt FW 1984 Preferential utilization of the most $J_{H}$-proximal $V_{H}$ gene segments in pre-B cell lines. Nature 311:727-733

72. Alt FW, Yancopoulos GD, Blackwell TK, Wood L, Thomas E, Boss M, Coffman R, Rosenberg N, Tonegawa S, Baltimore D 1984 Ordered rearrangement of immunoglobulin heavy chain variable region segments. EMBO J 3:1209-1219

73. Perlmutter RM, Kearney JF, Chang SP, Hood LE 1985 Developmentally controlled expression of immunoglobulin VH genes. Science 227: 1597-1601

74. Malynn BA, Yancopoulos GD, Barth JE, Bona CA, Alt FW 1990 Biased expression of $\mathrm{J}_{\mathrm{H}^{-}}$-proximal $\mathrm{V}_{\mathrm{H}}$ genes occurs in the newly generated repertoire of neonatal and adult mice. J Exp Med 171:843-859

75. Schroeder Jr HW, Hillson JL, Perlmutter RM 1987 Early restriction of the human antibody repertoire. Science 238:791-793

76. Schroeder Jr HW, Wang JY 1990 Preferential utilization of conserved immunoglobulin heavy chain variable region gene segments during human fetal life. Proc Natl Acad Sci USA 87:6146-6150

77. Buluwela L, Rabbitts TH $1988 \mathrm{~A} \mathrm{~V}_{\mathrm{H}}$ gene is located within $95 \mathrm{~kb}$ of the human immunoglobulin heavy chain constant region genes. Eur J Immunol 18:1843-1845

78. Humphries CG, Snen A, Kuziel WA, Capra JD, Blatner FR, Tucker PW 1988 A new human immunoglobulin $V_{H}$ family preferentially rearranged in immature B-cell tumors. Nature 331:446-449

79. Teale JM, Morris EG 1989 Comparison of $V_{\kappa}$ gene family expression in adult and fetal B cells. J Immunol 143:2768-2772

80. Kaushik A, Schultz DH, Bona C, Kelsoe G 1989 Murine $V_{\times}$gene expression does not follow the $\mathrm{VH}$ paradigm. J Immunol 169:1859-1864

81. Jeong HD, Teale JM 1990 Contribution of the CD5+ B cell to D-proximal $\mathrm{V}_{\mathrm{H}}$ family expression early in ontogeny. $\mathrm{J}$ Immunol 145:2725-2729

82. Yamada M, Wasserman R, Reichard BA, Shane S, Caton AJ, Rovera G 1991 Preferential utilization of specific immunoglobulin heavy chain diversity and joining segments in adult human peripheral blood B lymphocytes. J Exp Med 173:395-407

83. Feeney AJ 1990 Lack of $\mathrm{N}$ regions in fetal and neonatal mouse immunoglobulin V-D-J junctional sequences. J Exp Med 172:1377-1390

84. Teale JM $1985 \mathrm{~B}$ cell immune repertoire diversifies in a predictable temporal order in vitro. J Immunol 135:954-962

85. Klinman DM, Ishigatsubo Y, Steinberg AD 1988 Acquisition and maturation of expressed $B$ cell repertoires in normal and autoimmune mice. J Immunol 141:801-806

86. Pabst HF 1980 Ontogeny of the immune response as a basis of childhood disease. J Pediatr 97:519-534

87. Insel RA, Kittelberger A, Anderson P 1985 Isoelectric focusing of human antibody to the Haemophilus influenzae b capsular polysaccharides: restricted and identical spectrotypes in adults. J Immunol 135:2810-2816

88. Brockly F, Alexandre D, Chuchana P, Huck S, Lefranc G, Lefranc M-P 1989 First nucleotide sequence of a human immunoglobulin variable region gene belonging to subgroup II. Nucleic Acids Res 17:3976

89. Scott MG, Crimmins DL, McCourt DW, Zocher I, Theibe R, Zachau HG, Nahm MH 1989 Clonal characterization of the human IgG antibody response to Haemophilus influenzae type b polysaccharide. III. A single $V_{\kappa}$ II gene and one of several $J_{\kappa}$ genes are joined by an invariant arginine to form the most common L chain V region. J Immunol 143:4110-4116

90. Kato S, Tchibana K, Takayama N, Kataoka H, Yoshida MC, Takano T 1991 
Genetic recombination in a chromosomal translocation $\mathrm{t}(2 ; 8)(\mathrm{p} 11 ; \mathrm{q} 24)$ of a Burkitt's lymphoma cell line KOBK101. Gene 97:239-244

91. Chen PP, Liu M, Sinha S, Carson DA 1988 A 16/6 idiotype positive antiDNA antibody is encoded by a conserved VH gene with no somatic mutation. Arthritis Rheum 31:1429-1431

92. Silverman GJ, Lucas AH 1991 Variable region diversity in human circulating antibodies specific for the capsular polysaccharide of Haemophilus influenzae type b preferential usage of two types of $\mathrm{VH} 3$ heavy chains. J Clin Invest 88:911-920

93. Dersimonian H, Schwartz RS, Barrett KJ, Stollar BJ 1987 Relationship of human variable region heavy chain germline genes to genes encoding antiDNA antibodies. J Immunol 139:2496-2501

94. Pascual V, Randin I, Thompson K, Siovd M, Forre O, Natvig J, Capra JD 1990 The complete nucleotide sequences of six monospecific rheumatoid factors derived from Epstein-Barr virus transformed B cells isolated from the synovial tissue of patients with rheumatoid arthritis. Further evidence that some autoantibodies are unmutated copies of germ line genes. J Clin Invest 86:1320-1328

95. Scott MG, Crimmins DL, McCourt DW, Seigel NR, Smith CE, Nahm MH 1991 Clonal characterization of the human $\mathrm{IgG}$ antibody repertoire to
Haemophilus influenzae type b polysaccharide. IV. The less frequently expressed VL are heterogenous. J Immunol 147:4007-4013

96. Lucas AH, Granoff DM 1990 A major crossreactive idiotype associated with human antibodies to the Haemophilus influenzae b polysaccharide. Expression in relation to age and immunoglobulin $G$ subclass. J Clin Invest 85 $1158-1166$

97. Insel RA, Anderson Jr PW 1982 Cross-reactivity with Escherichia coli K100 in the human serum anticapsular antibody response to Haemophilus influenzae type b. J Immunol 128:1267-1270

98. Schneerson R, Robbins JB 1975 Induction of serum Haemophilus influenzae type b capsular antibodies in adult volunteers fed crossreacting Escherichia coli O75:K100:H5. N Engl J Med 292:1093-1096

99. Pascual V, Capra JD 1991 Human immunoglobulin heavy-chain variable region genes: organization, polymorphisms, and expression. Adv Immunol 49:1-70

100. Carson DA, Chen PP, Kipps TJ 1991 New roles for the rheumatoid factor. J Clin Invest 87:379-383

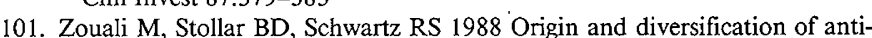
DNA antibodies. Immunol Rev 105:137-158

102. Kipps TJ 1989 The CD5 B Cell. Adv Immunol 47:117-185 